\title{
DIAGNÓSTICO AMBIENTAL INTEGRADO DO MUNICÍPIO DE GROSSOS/RN: SUBSÍDIOS AO PLANEJAMENTO AMBIENTAL
}

\author{
Rodrigo Guimarães de Carvalho ${ }^{1}$ \\ Fátima Maria Soares Kelting ${ }^{2}$ \\ Ponciana Freire de Aguiar $^{3}$
}

Resumo: O presente artigo trata da análise ambiental integrada do município de Grossos. Os sistemas ambientais do município foram delimitados e analisados segundo a escala de 1: 40.000. Para a consecução do trabalho foram seguidas etapas de revisão bibliográfica e documental, trabalhos de campo, interpretação de imagem de satélite e cartografia digital. A análise da estrutura e dinâmica natural dos sistemas ambientais, associada ao estudo das condições de uso e cobertura da terra possibilitou a confecção de um quadro-diagnóstico onde são evidenciadas as potencialidades e limitações ao uso e os problemas ambientais emergentes.

Palavras-Chave: Análise Ambiental Integrada; Dinâmica Ambiental; Município de Grossos.

\section{INTEGRATED ENVIRONMENTAL DIAGNOSIS OF THE MUNICIPALITY OF GROSSOS/STATE OF RIO GRANDE DO NORTE: SUBSIDIES TO ENVIRONMENTAL PLANNING}

\begin{abstract}
This article presents the integrated environmental analysis of the municipality of Grossos. The environmental systems of the municipality were delimited and analyzed using the 1:40,000scale. For the development of the work steps of bibliographic and document review, fieldwork, interpretation of satellite image and digital cartography were carried out. The analysis of the structure and natural dynamics of the environmental systems, associated to the study of the land use and coverage conditions enabled the confection of a diagnostic framework where the potential and limitations to the use and the emerging environmental problemsare highlighted.
\end{abstract}

Key-Words: Integrated Environmental Analysis; Environmental Dynamics; Municipality of Grossos.

\section{INTRODUÇÃO}

A análise ambiental integrada e sistêmica constitui uma busca pelo conhecimento sobre a estrutura e funcionamento do meio ambiente em seu conjunto de componentes. No âmbito da Geografia, especificamente da Geografia Física, os estudos ambientais têm sido tratados sob o enfoque sistêmico com a interpretação das paisagens de forma integrada,

\footnotetext{
${ }^{1}$ Bacharelado em Geografia, Especialização em Planejamento e Gestão Ambiental, Mestrado em Geologia, Doutorado em Geografia, Professor Adjunto na Universidade do Estado do Rio Grande do Norte-E-mail: rodrigocarvalho@uern.br

${ }^{2}$ Graduada em Geografia, Mestrado em Geografia, Doutora em Geografia, Professora Associado II na Universidade Federal do Ceará - Email: doninha@ufc.br

${ }^{3}$ Graduação em Geografia, Mestrado em Geologia, Doutorado em Geologia e Geoquímica, professora substituta do Dep. de Geografia Universidade Federal do Ceará - E-mai: poncianafreire@gmail.com DOI: 10.7154/RDG.2012.0023.0005
} 
considerando-se essencialmente a estrutura e os processos interativos entre os diversos componentes ambientais.

Macedo (1995) destaca que a análise ambiental sistêmica deve ir além do enfoque cartesiano, responsável por fragmentar o objeto de análise em quantas partes forem possíveis. Esta abordagem também é conhecida como reducionismo ou mecanicismo. Devese ter como objetivo central, na medida do possível, trabalhar sob um enfoque holístico e sistêmico, considerando a observação do objeto na forma de sua totalidade, assim como, percebendo as interrelações entre suas partes internas.

Contudo, Macedo (op. cit.) reconhece que instrumentos da abordagem cartesiana devem e precisam fazer parte da avaliação ambiental, sendo necessário que outras ferramentas sejam utilizadas e aplicadas para globalizar as conclusões e resultados. Da mesma forma, Bertrand (1969) considera que os estudos ambientais definidos sob uma abordagem sistêmica não substituem nem concorrem com os estudos especializados tradicionais. Pelo contrário, valem-se destes para construir suas análises com maior clareza e segurança.

Com a inserção da concepção sistêmica nos trabalhos de Geografia Física, surgiram termos como, por exemplo, unidade geoambiental, unidade geoecológica e unidade de paisagem. O termo "unidade" expressa tudo que pode ser considerado individualmente, não significando, porém, que seja algo simples. Pode ser composta por agrupamentos de componentes que mantenham relações mútuas. Sendo assim, as unidades espaciais são entidades particulares, únicas e que representam uma configuração estrutural e funcional que as diferencie do seu entorno (CRISTOFOLETTI, 1999).

Na concepção geossistêmica da análise ambiental percebe-se a vinculação em um mesmo nível de importância, de todos os componentes ambientais na evolução do sistema, sendo inclusive possível, a inserção da variável antrópica uma vez que essa demonstre competência e significância nas interações com o ambiente. Como expressa Christofoletti (1999, p. 44), sobre a perspectiva holística de análise dos sistemas ambientais físicos, "não se pode excluir o conhecimento provindo dos estudos sobre os sistemas socioeconômicos". Porém, é preciso destacar que, como mencionam Bertrand e Bertrand (2007), a existência de um componente antrópico não significa que este seja subordinado ao geossistema, pois as relações internas nos geossistemas são submetidas às leis naturais, enquanto que a ação antrópica está submetida às leis socioeconômicas. Sendo assim, a ação antrópica se posiciona como uma relação externa e dialética ao geossistema. 
Esta pesquisa expõe a aplicação dos métodos da análise ambiental integrada no estudo do município de Grossos, pertencente ao estado do Rio Grande do Norte (RN). O referido município situa-se na Região Oeste do RN, mais precisamente no baixo curso da bacia hidrográfica do rio Apodi-Mossoró (Figura 1). Apresenta uma área de aproximadamente 126 $\mathrm{km}^{2}$ e um contexto de exploração econômica baseado em atividades agropecuárias, na pesca e especialmente na extração de sal marinho. A organização do território de Grossos é uma estratégia fundamental para a manutenção da qualidade de vida da população e conservação da natureza. Essa organização deve primar pelo ordenamento das atividades econômicas frente às potencialidades e limitações dos sistemas ambientais.

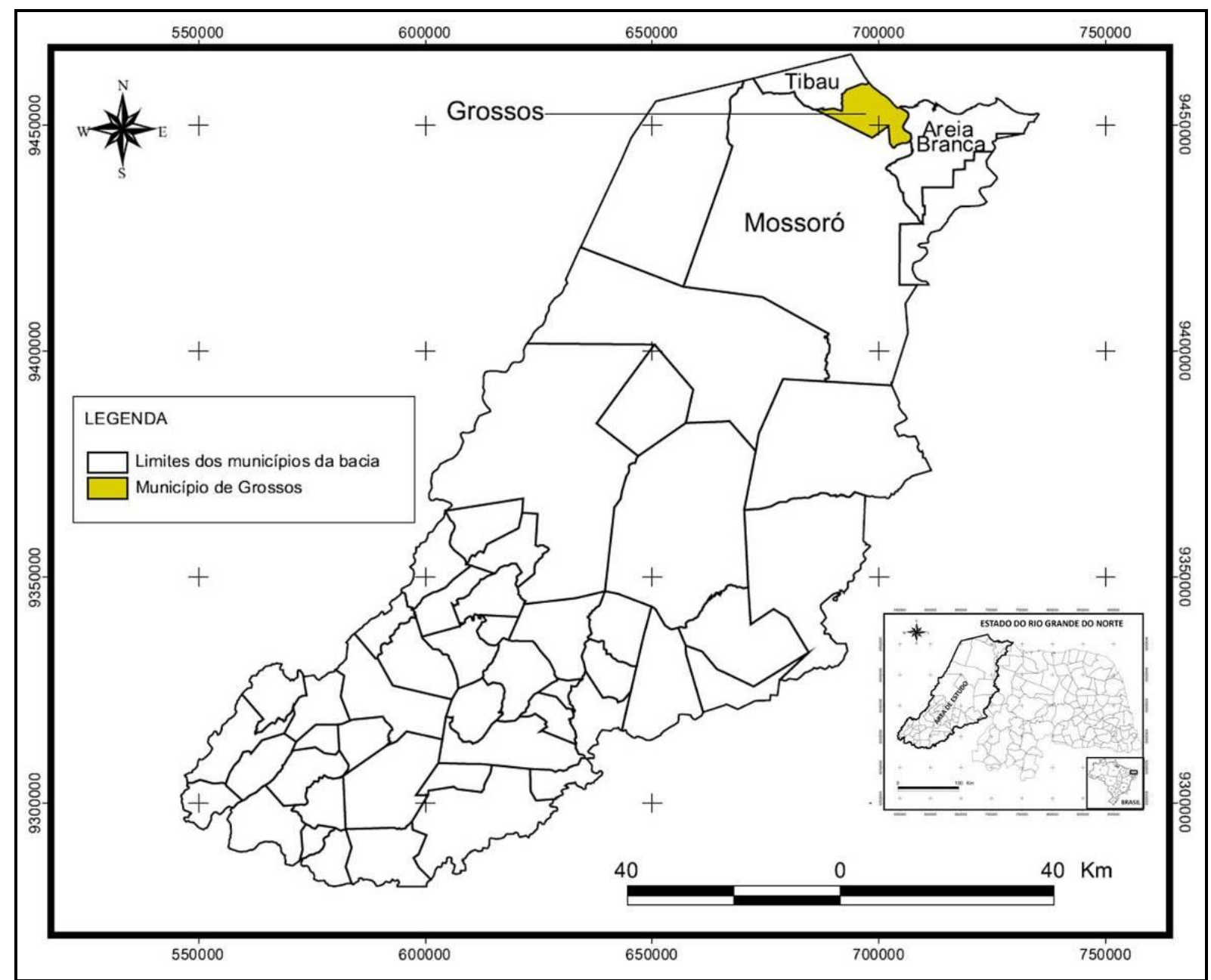

Figura 1 - Localização geográfica do município de Grossos, RN. Fonte: Carvalho (2011).

Sendo assim, o objetivo geral da presente pesquisa foi elaborar um diagnóstico ambiental, integrando os dados provenientes da análise dos sistemas ambientais físicos e da exploração socioeconômica no município de Grossos. Foram objetivos específicos: 
$\checkmark$ compartimentar os sistemas ambientais do município de Grossos em escala de 1:40.000;

$\checkmark$ analisar a dinâmica natural nos sistemas ambientais;

$\checkmark$ caracterizar o uso e a cobertura da terra no território de Grossos;

$\checkmark$ avaliar as potencialidades, limitações e os problemas de degradação e conflitos nos sistemas ambientais.

\section{MATERIAL E MÉTODOS}

Foram utilizados os seguintes equipamentos e materiais no desenvolvimento desta pesquisa:

$\checkmark \quad$ Computador de mesa: PC, Pentium IV, $2.000 \mathrm{MH}, \mathrm{HD}$ de $80 \mathrm{~GB}$ e 2 GB de Memória RAM;

$\checkmark \quad$ Software de entrada e manipulação de dados: Arcview GIS 3.2;

$\checkmark \quad$ Verificação de imagens de satélite: Google Earth Pro;

$\checkmark \quad$ Impressora Modelo HP Deskjet F4280;

$\checkmark \quad$ Aparelho GPSMAP 76CSx;

$\checkmark \quad$ Aparelho de gravação de voz COBY - CXR190-1G;

$\checkmark \quad$ Máquina fotográfica digital: SONY DSC, Resolução 8 Mega Pixels;

$\checkmark \quad$ Imagem de satélite: ALOS, ano de 2009;

$\checkmark \quad$ Arquivos cartográficos digitais:

- Tipologia do relevo, Declividade e Hipsometria (SEMARH - RN);

- Geologia e derivados (CPRM);

- Tipologia dos solos (EMBRAPA);

- Rede Hidrográfica (SEMARH - RN);

- Poligonais dos municípios e mesoregiões (IBGE);

- Desmatamento (MMA).

A etapa inicial da pesquisa objetivou o levantamento e análise de informações secundárias sobre o município de Grossos. Realizou-se uma ampla pesquisa bibliográfica, documental e de materiais geocartográficos, considerando as principais temáticas discutidas, como por 
exemplo, a teoria dos geossistemas, a dinâmica de paisagens litorâneas, o uso e ocupação no município de Grossos, entre outras.

$\mathrm{Na}$ etapa seguinte desenvolveu-se a organização e análise do material cartográfico préexistente sobre o município de Grossos. Para a atualização e mapeamento cartográfico, a área de estudo foi enfocada na escala de 1: 40.000. Nessa escala a análise deve ser voltada ao diagnóstico ambiental, intensidade de uso, impactos ambientais, perigos, riscos e vulnerabilidade e evolução do sistema de gestão ambiental (RODRIGUEZ et. al., 2010). Devese alcançar um bom nível de detalhes, compreendendo-se as inter-relações entre as características físicas e biológicas e as ações antrópicas (CENDRERO, 1989 apud SANTOS, 2004).

O mapa de compartimentação dos sistemas ambientais foi obtido pela análise e sobreposição dos shapes files temáticos sobre geologia, geomorfologia e solos, utilizando o software Arcview GIS 3.2. Já o mapa de uso e ocupação foi elaborado a partir da interpretação visual da imagem ALOS de 2009, em conjunto com atividades de campo para o reconhecimento da verdade terrestre.

A análise das potencialidades e limitações dos sistemas ambientais figura como uma etapa importante. Nesse momento foram confrontados os elementos que interagem no ambiente mediante a dinâmica ambiental. A potencialidade de uso de recursos naturais está ligada aos possíveis componentes do meio que, de acordo com a estrutura socioeconômica de um território, poderão ser utilizados e beneficiados de modo a favorecer a produção e distribuição de riquezas dentro da ótica da sustentabilidade. As limitações são descritas como situações desfavoráveis a exploração de recursos naturais, podendo ser originárias da própria estrutura e capacidade produtiva dos sistemas ambientais, de uma situação específica como a falta de infraestrutura disponível ou tecnologia adequada para exploração, ou até mesmo de restrições legais referentes a proteção de determinados componentes da paisagem, ecossistemas ou unidades de conservação.

Já os problemas ambientais representam situações de degradação ambiental ou o estabelecimento de determinados conflitos ambientais. Estes foram identificados por meio de pesquisa de campo, registro fotográfico e aplicação de entrevistas abertas com moradores do município. 


\section{RESULTADOS E DISCUSSÃO}

\section{Contexto geoambiental do município de Grossos e compartimentação dos sistemas}

\section{ambientais}

A geologia do município é dominada por estruturas sedimentares. Cinco unidades geológicas afloram no território de Grossos, compreendendo os Depósitos Litorâneos, os Depósitos Flúvio-Marinhos, os Depósitos Flúvio-Lacustres, a Formação Barreiras e a Formação Jandaíra. A Formação Barreiras é a unidade de maior abrangência territorial, ocupando uma área de aproximadamente 7.820 ha, equivalente a $57 \%$ do território municipal como pode-se observar na Tabela 1.

A unidade de menor expressão territorial são os Depósitos Flúvio-Lacustres, com apenas 228 ha, atingindo $1 \%$ da área total. Salienta-se que essa unidade foi mapeada em conformidade com a escala cartográfica adotada nesta etapa da pesquisa (1:40.000), na qual admite-se que, algumas áreas de depósitos fluviais recentes não puderam ser representadas no mapa, por suas pequenas dimensões territoriais.

Tabela 1 - Unidades geológicas do município de Grossos em hectares e percentual.

\begin{tabular}{lll}
\hline Unidades geológicas & $\begin{array}{l}\text { Área } \\
\text { Hectares }\end{array}$ & em \\
\hline Depósito Litorâneo & 2.330 & 17 \\
Depósito Flúvio-Marinho & 2.723 & 20 \\
Depósito Flúvio-Lacustre & 228 & 1 \\
Formação Barreiras & 7.820 & 57 \\
Formação Jandaíra & 741 & 5 \\
\hline TOTAL & $\mathbf{1 3 . 8 4 2}$ & $\mathbf{1 0 0}$ \\
\hline
\end{tabular}

A geomorfologia e a tipologia de solos do município de Grossos possuem correspondência direta com a composição litológica. Cada tipo de depósito, em sua evolução e interação com outros componentes do meio, especialmente os climáticos e marinhos, dão conformidade a tipologias próprias de relevo e solos. Desse modo, destaca-se no Quadro 1 um paralelo entre a litologia, os domínios geomorfológicos e a tipologia de solos correspondentes. 


\begin{tabular}{|l|l|l|}
\hline UNIDADES GEOLÓGICAS & $\begin{array}{l}\text { DOMíNIOS } \\
\text { GEOMORFOLóGICOS }\end{array}$ & SOLOS PREDOMINANTES \\
\hline Depósito Litorâneo & $\begin{array}{l}\text { Planície Litorânea } \\
\text { Subcompartimentos: } \\
\end{array}$ & $\begin{array}{l}\text { - faixa de praia e dunas frontais; } \\
\text { - terraço marinho; } \\
\text { - campo de dunas. }\end{array}$ \\
\hline Depósito Flúvio-Marinho & Planície Flúvio-Marinha & \\
\hline Depósito Flúvio-Lacustre & Planície Flúvio-Lacustre & Gleissolo Sálico \\
\hline Formação Barreiras & Tabuleiro Costeiro & Latossolnico \\
\hline Formação Jandaíra & Chapada do Apodi & Cambissolo \\
\hline
\end{tabular}

Quadro 1 - Unidades geológicas do município de Grossos e domínios geomorfológicos. Fonte: Carvalho (2011).

A planície litorânea representa a unidade de relevo, morfologicamente, mais diversificada, sendo constituída pela faixa de praia e dunas frontais, pelo terraço marinho e pelos campos de dunas móveis. A planície flúvio-marinha corresponde a um tipo de relevo formado a partir de processos costeiros complexos, com destaque para o papel da sedimentação fluvial e marinha, apresenta morfologia suave, submetida à intensa e constante dinâmica de sedimentos. Já as planícies flúvio-lacustres abrangem áreas de sedimentação fluvial acopladas a pequenas bacias de inundação sazonal, sendo utilizadas por disporem de água, embora que sazonalmente, e por terem solo de boa fertilidade para o cultivo agrícola. 0 tabuleiro costeiro apresenta morfologia plana, sendo essa monotonia quebrada apenas pelos rios que o cortam, mas com baixa capacidade de entalhe. Já a chapada do Apodi, corresponde a um afloramento justificado pela erosão lateral da Formação Barreiras pela ação flúvio-marinha, sendo que, nesse ambiente geomorfológico, a morfogênese atuou, criando um rampeamento com caimento direcionado para o rio Apodi-Mossoró (leste), e, condicionando uma pequena rede de drenagem intermitente nesse mesmo sentido.

Os solos existentes no município de Grossos também têm forte relação com os componentes geológico-geomorfológicos. Na planície litorânea predomina o neossolo quartzarênico. Na planície flúvio-marinha ocorre, marcadamente, o gleissolo sálico. Nas planícies flúvio-lacustre e fluviais predomina o neossolo flúvico e no tabuleiro costeiro, ocorre o latossolo vermelho amarelo. Em termos de aproveitamento para a agricultura, os mais recomendados nesse caso, são os neossolos flúvicos, desde que sejam respeitados os limites das áreas de preservação permanente e controlado o uso de agrotóxicos. Já os latossolos, mesmo com uma baixa fertilidade natural, têm grande potencial se manejados adequadamente. Nesse último caso, tanto o relevo plano, como a grande área de 
abrangência no município de Grossos, são fatores favoráveis a sua utilização para agricultura.

O clima característico do município de Grossos é o BSw'h', segundo a classificação climática de Köppen. Predominam altas temperaturas, conduzindo a um clima muito quente e semiárido, com estação chuvosa atrasando-se para o outono. A precipitação média anual fica em torno de 600 a $700 \mathrm{~mm}$ (SEMARH, 1998). A temperatura média anual é de $27,3^{\circ} \mathrm{C}$, com variação entre a máxima de $36,0^{\circ} \mathrm{C}$ e mínima de $21,0^{\circ} \mathrm{C}$.

A hidrografia superficial possui baixa densidade de cursos d'água, sobretudo em função do clima semiárido associado à alta permeabilidade dos terrenos sedimentares. A maior parte da drenagem percorre o tabuleiro costeiro no sentido SO-NE. Quando atingem as proximidades da planície litorânea, os terrenos mais rebaixados conduzem a extrapolação dos leitos, formando, com isso, pequenas lagoas intermitentes sazonais. Na planície litorânea predominam as lagoas intermitentes de origem freática. Praticamente em toda a área de deflação eólica e nas depressões interdunares, afloram uma infinidade de lagoas que aumentam consideravelmente sua lâmina d'água nos meses de maior pluviometria. Posteriormente, com a interrupção das chuvas, elas retrocedem até secar completamente, deixando apenas o solo úmido, recoberto por vegetação herbácea adaptada. O rio ApodiMossoró, em sua área estuarina, define o limite leste do município, onde predominam atividades de pesca e, em especial a atividade salineira.

No que se refere ao potencial de águas subterrâneas do município de Grossos, cabe destacar os dois domínios hidrogeológicos existentes: o domínio hidrogeológico intersticial e o domínio hidrogeológico kárstico-fissural. O primeiro é composto por rochas sedimentares da Formação Barreiras, Depósitos Litorâneos, Flúvio-Lagunares e Aluvionares, enquanto que o segundo é constituído pelos calcários da Formação Jandaíra (CPRM, 2005). Uma pesquisa desenvolvida pela CPRM em 2005 investigou 47 poços tubulares na área do município. Deste total, $33(70,20 \%)$ foram avaliados em testes de condutividade e, 31 apresentaram águas salobras ou salgadas.

Quanto ao uso da água desses poços, $13 \%$ dos pontos cadastrados são destinados ao consumo humano (para beber), $27 \%$ são utilizados no consumo humano para uso geral, $18 \%$ são para uso na agricultura, 5\% para dessedentação animal e 37\% para outros usos (CPRM, 2005). Os resultados apontam a necessidade de instalação de dessalinizadores para 
melhorar a qualidade da água consumida pela população, sobretudo nos poços comunitários.

A distribuição da vegetação no município de Grossos está condicionada por fatores naturais, referentes ao fluxo de energia e à matéria, e, também, aos fatores de intervenção antrópica. Iniciando na faixa de berma e primeiras dunas frontais, encontram-se espécimes da vegetação pioneira psamófila, amplamente consorciada com algorobas (Prosopis juliflora), plantadas com a finalidade de reter o avanço dos sedimentos sobre as comunidades litorâneas (Figura 2).

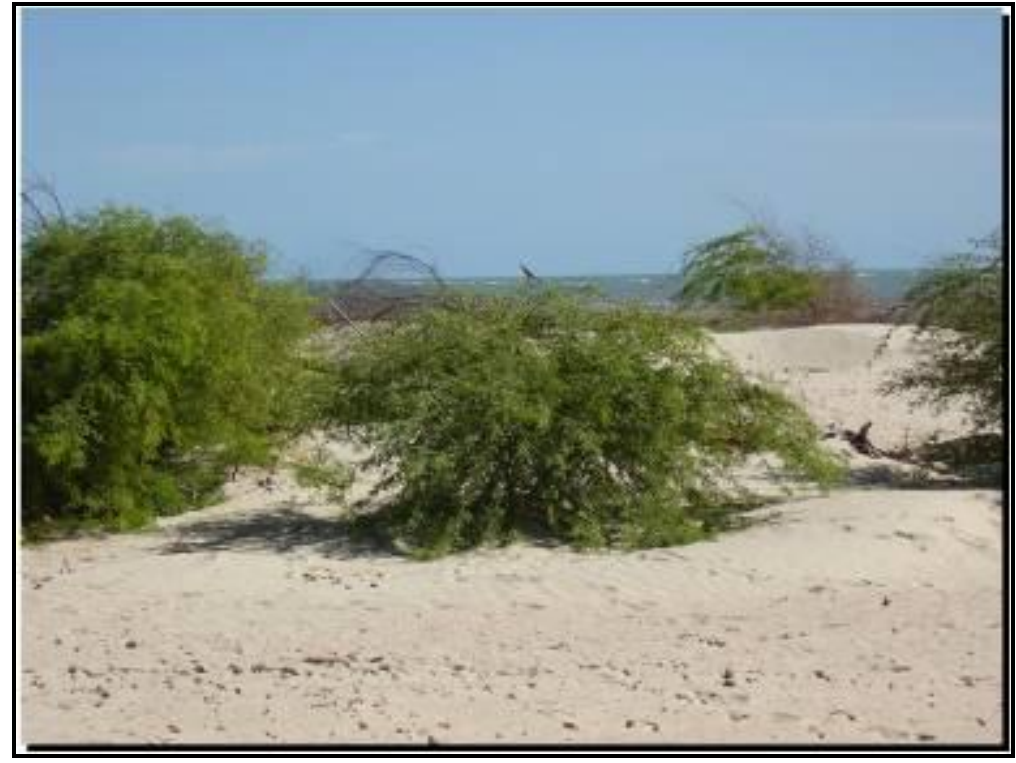

Figura 2 - Algarobas na faixa de berma e dunas frontais próximo a comunidade de Pernambuquinho, Grossos, RN, em janeiro de 2011.

Fonte: Carvalho (2011).

Outra espécie bastante presente na planície litorânea é o coqueiro (Cocos nucifera). Esta se distribui por toda a área do terraço marinho, com um maior adensamento próximo a comunidade de Areias Alvas e Valença. No contexto de exploração do litoral brasileiro o coqueiro possui grande importância econômica, sendo utilizado na produção de óleo, como subsistência para pequenos agricultores, na produção de bebidas e alimento para os animais (SIQUEIRA; ARAGÃO; TUPINAMBÁ, 2002).

Nos setores de terraço marinho e depressões interdunares verificou-se a presença de vegetação herbácea, sobretudo nos setores que resguardam alguma umidade no solo (Figura 3). Por vezes, apresentam-se consorciadas a algarobas (Figura 4). 


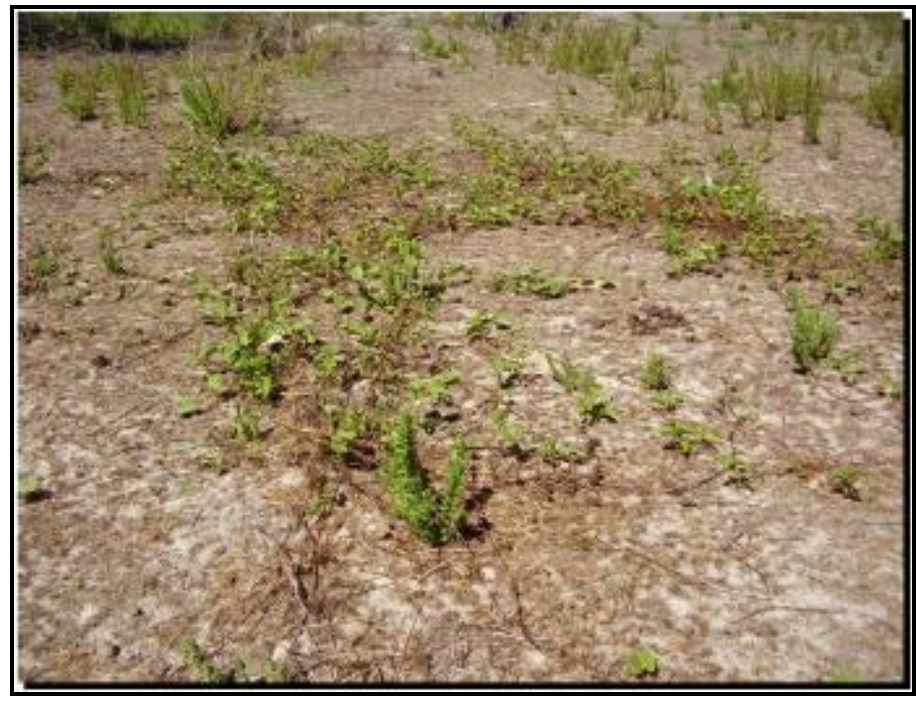

Figura 3 - Vegetação herbácea no setor de depressão interdunar, Grossos, RN. Fonte: Carvalho (2011).

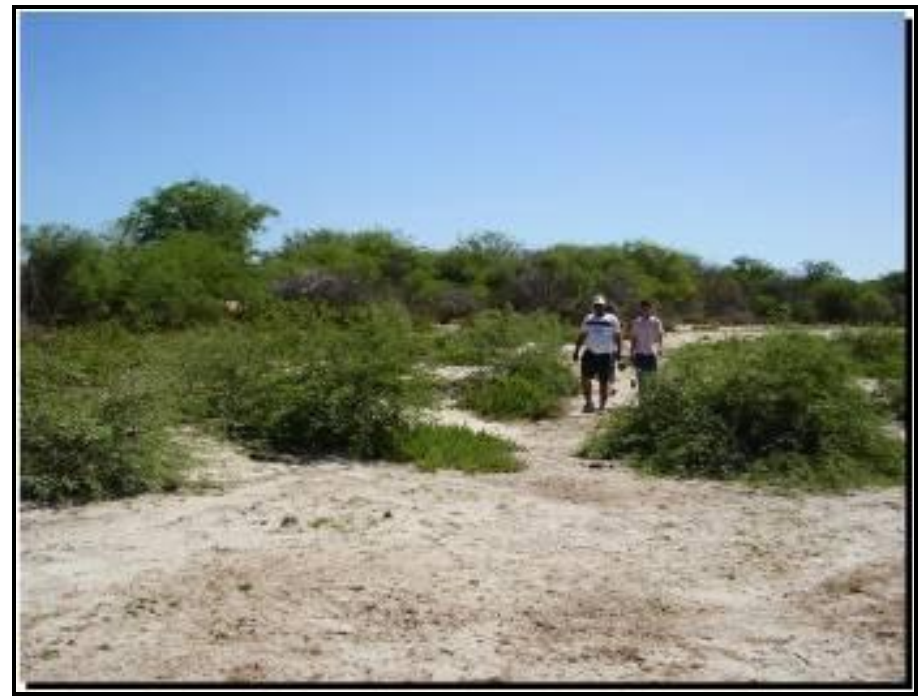

Figura 4 - Algarobas no terraço marinho do município de Grossos, RN. Fonte: Carvalho (2011).

Em alguns setores da planície de deflação eólica, ainda podem ser encontrados remanescentes de carnaúba (Copernicia prunifera). Existe uma pequena concentração próxima a comunidade de Valença (Figura 5).

Na planície flúvio-marinha ocorre a presença de remanescentes de vegetação de mangue. Estes vêm sendo, ao longo do tempo, devastados pelas atividades das salinas, as quais atuam no Estado do Rio Grande do Norte desde o século XVIII. A maior área remanescente está alocada na desembocadura do rio Apodi-Mossoró, na margem esquerda, próximo a comunidade de Barra. A partir desse remanescente principal, o mangue se estende rio acima, sempre bordejando a área de salinas. É uma estreita faixa de vegetação de mangue, apresentando processos de degradação nítidos como o acúmulo de lixo proveniente da área urbana e dos estabelecimentos comerciais que funcionam próximos ao mangue. 


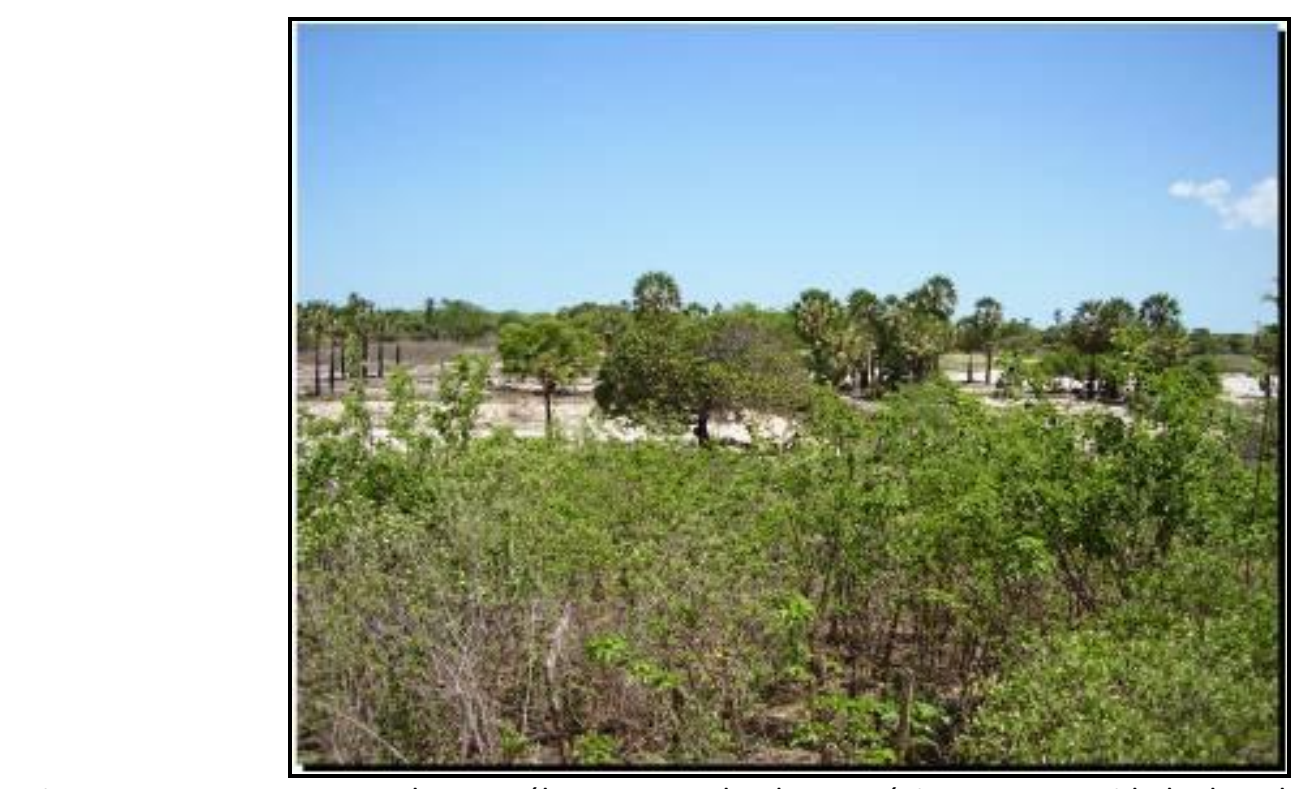

Figura 5 - Remanescentes de carnaúba no segundo plano, próximos a comunidade de Valença, município de Grossos, RN.

Fonte: Carvalho (2011).

No setor do tabuleiro costeiro, predomina a vegetação típica de caatinga hiperxerófila arbustiva. Constitui-se numa vegetação de caráter mais seco, com abundância de cactáceas e plantas de porte mais baixo e espalhado. Entre outras espécies destacam-se a juremapreta (Mimosa tenuiflora), mufumbo (Cobretum leprosum), faveleiro (Cnidoscolus phyllacanthus), marmeleiro (Croton hemiargyreus), xique-xique (Pilosocereus gounellei) e facheiro (Pilosocereus pachycladus) (IDEMA, [entre 2000 e 2010]). Os dados sobre o monitoramento do bioma caatinga (MMA, 2010) revelam que o município de Grossos, até 2008, possuía cerca de 36,62\% de áreas desmatadas no domínio da vegetação de caatinga.

O mapa de compartimentação dos sistemas ambientais pode ser visualizado na Figura 6 . As unidades de relevo foram utilizadas como referência para a demarcação dos limites dos sistemas ambientais uma vez que são passíveis de uma delimitação mais clara.

\section{Dinâmica geoambiental}

A compreensão da dinâmica geoambiental atual no município de Grossos incorpora, como requisito inicial, a caracterização das principais unidades morfológicas existentes, assim como, as conformações litológicas, os tipos de solo e o revestimento vegetal. Dependendo de como estejam agrupados estes componentes, os mesmos se apresentarão mais ou menos susceptíveis a ação dos processos modeladores do litoral. 


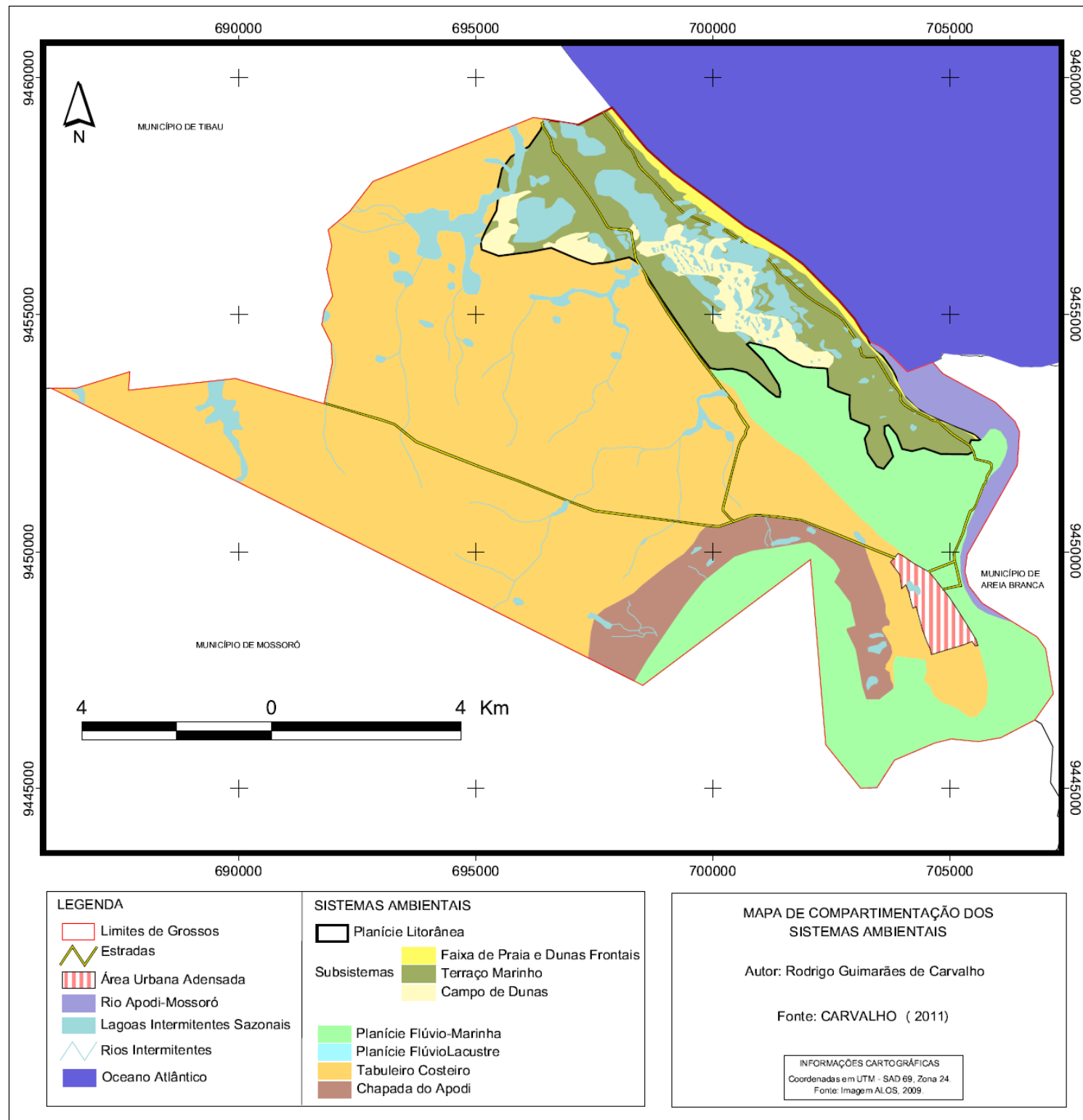

Figura 6 - Mapa de compartimentação dos sistemas ambientais.

Adaptado de Carvalho (2011).

Os processos ora mencionados estão ligados a uma conjuntura de fatores, com destaque para: a ação das ondas, correntes e marés; transporte fluvial; ação eólica; ação pluvial e força gravitacional. Silva (1998) comenta que o intenso fluxo de matéria e energia nos ambientes costeiros leva a gênese de processos que resultam na constituição de paisagens com uma intensa dinâmica espaço-temporal. Em estudo sobre a planície costeira do estado do Ceará, Meireles, Silva e Thiers (2006) evidenciaram seis tipos de fluxos de energia, quais sejam: o processo gravitacional, a deriva litorânea, o transporte eólico, o sistema estuarino, o fluxo flúvio-lagunar e as águas subterrâneas.

No estudo desses fenômenos, cabe inicialmente uma apreciação do espaço geográfico em análise com o intuito de evidenciar uma modelagem a partir da interpretação de indicadores 
morfológicos locais. Assim sendo, considerando-se os processos que atuam e dão sentido a dinâmica ambiental no município de Grossos, iniciar-se-á a discussão, apresentando um modelo simplificado de fluxos de energia e matéria nos sistemas litorâneos do município mencionado (Figura 7).

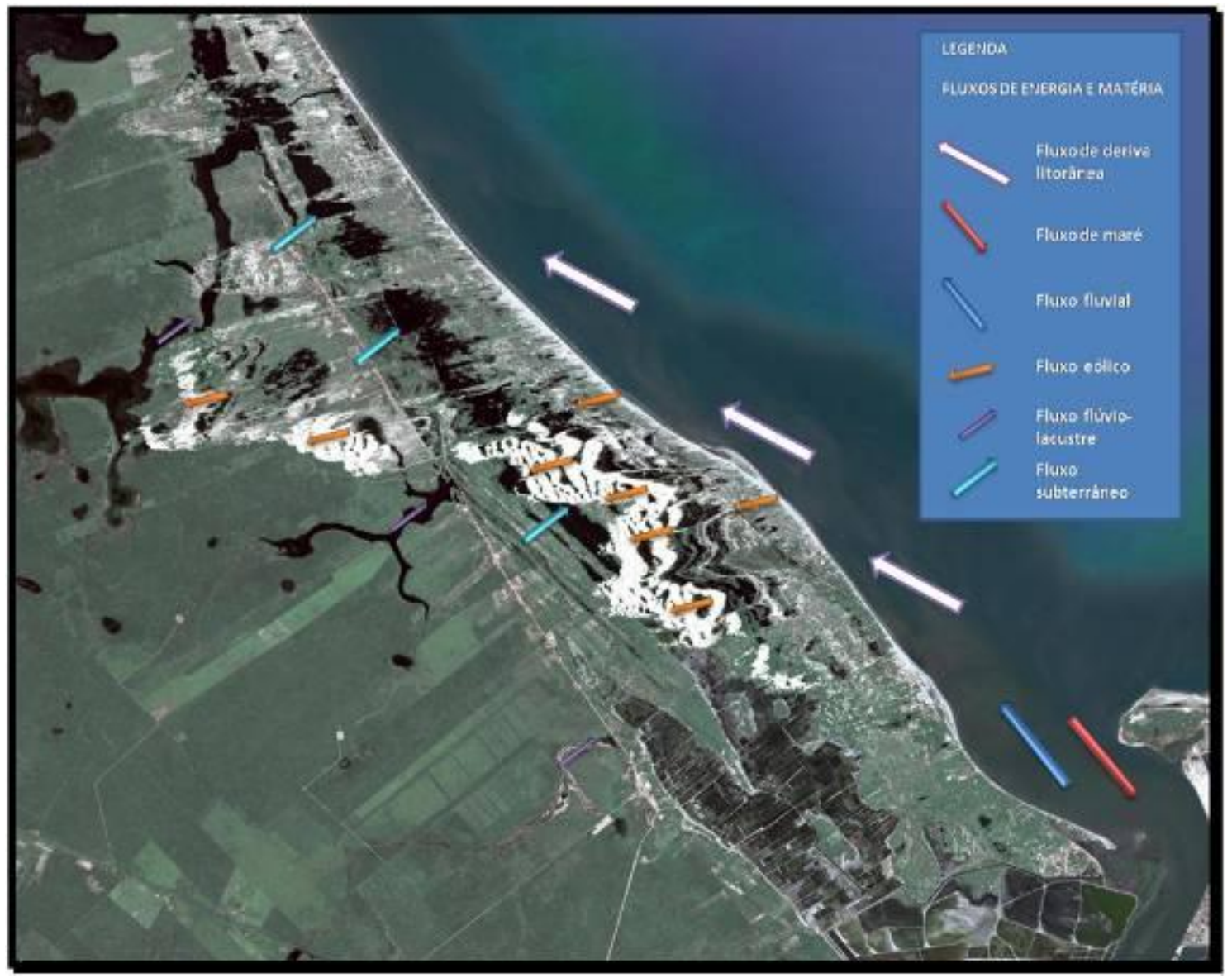

Figura 7 - Modelo de fluxos de energia e matéria no litoral do município de Grossos, RN. Fonte: Carvalho (2011).

A planície litorânea do município de Grossos é constituída por subcompartimentos morfológicos que funcionam como importantes indicadores da evolução da linha de costa, sobretudo entre o Pleistoceno e o Holoceno. Compreender o funcionamento dessa paisagem significa, também, uma apreciação sobre seu comportamento futuro, o que pode servir como subsídio para que se tenha um uso planejado e sustentável dessas áreas.

A faixa de praia e as dunas frontais são as áreas mais instáveis da planície litorânea, e são influenciadas diretamente pelo estuário do rio Apodi-Mossoró quanto à disponibilização de sedimentos. As correntes de deriva litorânea que atuam no sentido de leste para oeste (VITAL, 2006, p. 163) transportam esses sedimentos e os redistribuem nas faixas de praia adjacentes. Contudo, essas mesmas correntes também podem atuar na abrasão e na erosão 
das costas dependendo do balanço sedimentar regional e local. Em entrevistas informais com habitantes que já residem há algumas décadas próximo a praia, observou-se um discurso homogêneo sobre o perceptível avanço do nível do mar nos últimos anos. Essa informação foi corroborada na pesquisa de campo, visto que em todo o percurso da faixa de praia constatou-se evidências de erosão (Figura 8).

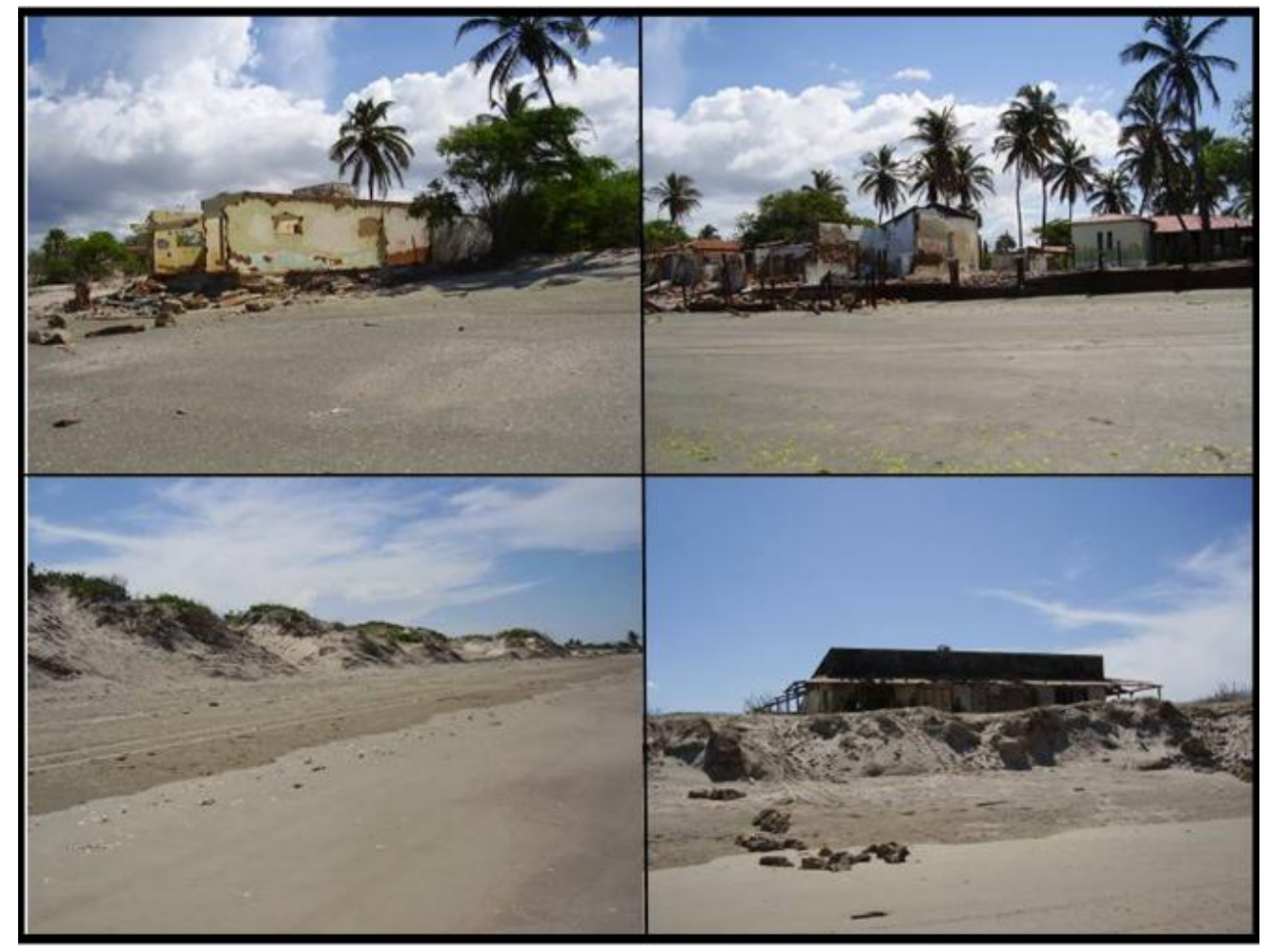

Figura 8 - Evidências de erosão na faixa de praia do município de Grossos. Fonte: Carvalho (2011).

As dunas frontais se formam após a faixa de berma. Conforme Rabêlo e Brito (2004, p. 01), “a sua gênese e evolução estão ligadas a existência de transporte eólico, da praia para o interior do continente, e à capacidade de retenção de areia por parte da vegetação costeira, que vai aprisionar o sedimento, dando assim origem a formação de dunas". Segundo Hesp (2002) elas também recebem outras denominações, tais como: dunas embrionárias (embryo dunes), cristas de retenção (retention ridges), cristas de praia (beach ridges), cordões de dunas paralelas (parallel dune ridges) e dunas transversais (transverse dunes). Observa-se em uma grande parte da faixa de praia de Grossos, conjuntos de dunas frontais junto a uma disseminação importante de algarobas (Figura 9), que, como citado anteriormente, tem como intuito principal minimizar os problemas causados pela migração dos sedimentos continente adentro, mobilizados pelo intenso regime de ventos. Outros tipos de intervenção 
também foram constatados como, por exemplo, a fixação de palhas de coqueiros e a construção de pequenos muros de contenção de areia.

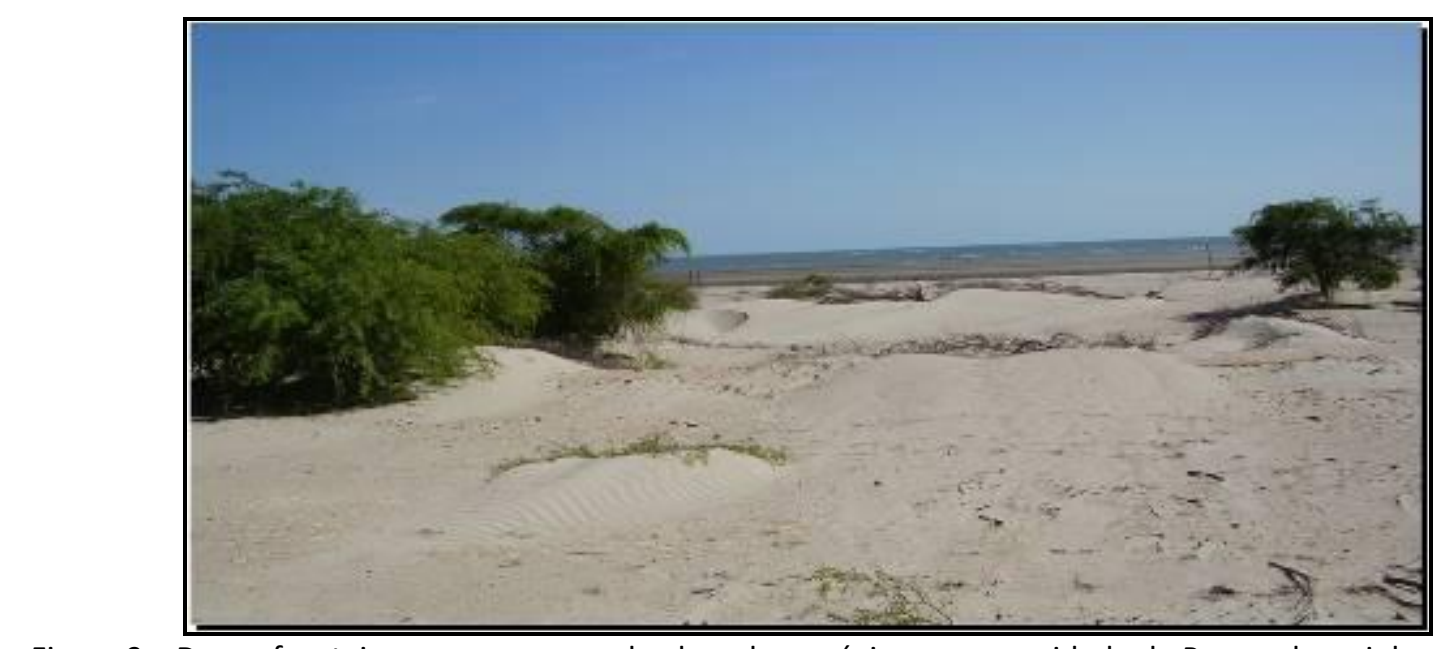

Figura 9 - Dunas frontais com a presença de algarobas próximo a comunidade de Pernambuquinho, município de Grossos, RN.

Fonte: Carvalho (2011).

Apesar das intervenções e tentativas de controle da migração dos sedimentos, vários pontos da rodovia litorânea, assim como casas, mesmo as que estão afastadas até 200 metros da linha de preamar, tem sido constantemente soterradas, sendo necessárias, dessa forma, ações constantes do poder público por meio do uso de tratores para a retirada da areia (Figura 10).

O terraço marinho compreende uma superfície horizontal modelada por erosão marinha, associada aos períodos de regressão e transgressão marinha que ocorreram durante o Pleistoceno e o Holoceno. Em Grossos, esta superfície se estende desde o pós-praia até o contato com o tabuleiro costeiro (Formação Barreiras), formando uma ampla planície com uma média de 2.000 metros de largura, chegando em algumas áreas a 4.000 metros. Tem altitude variando de 0 a 1 metro em relação ao nível do mar. Em alguns setores encontramse evidenciadas superfícies de deflação eólica ativas, responsáveis por manter a alimentação dos campos de dunas por sedimentos provenientes da faixa de praia. Em toda a superfície do terraço marinho afloram inúmeras lagoas freáticas, resultado do acúmulo de água nos períodos de maior pluviometria, combinado com a alta permeabilidade e baixa altitude. 


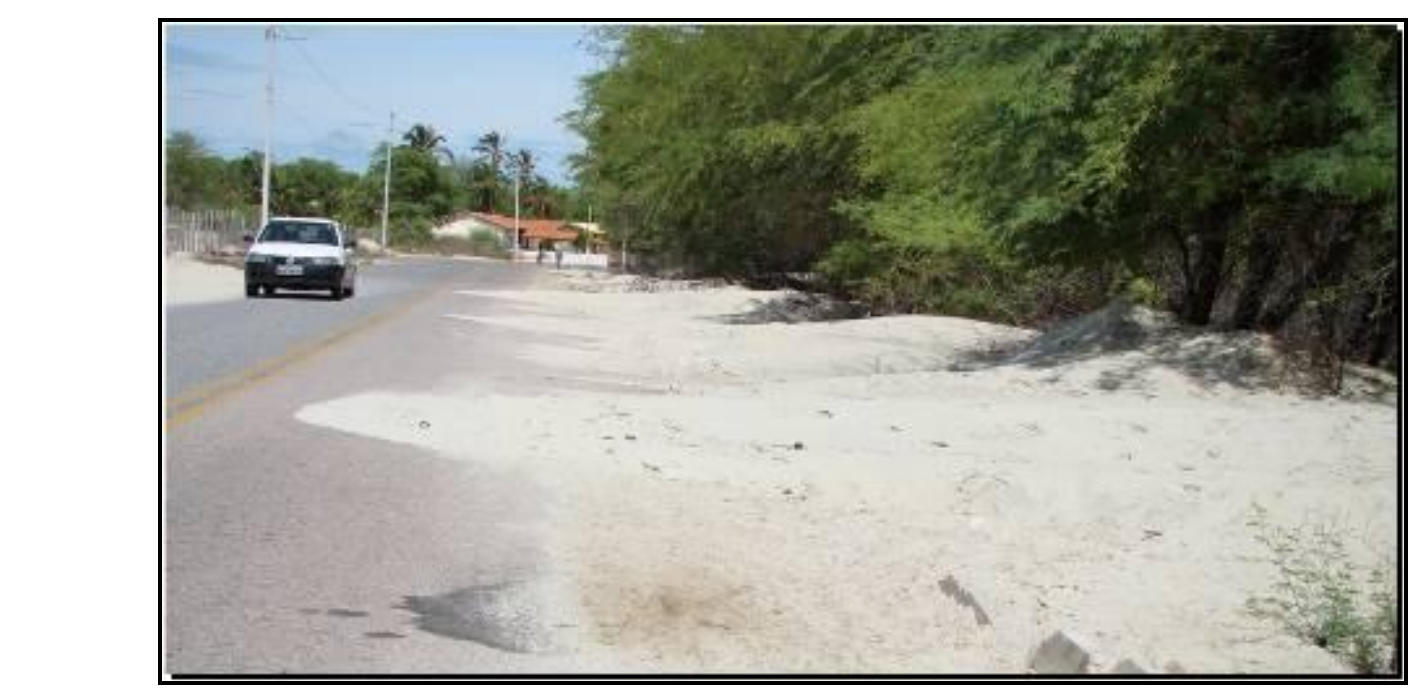

Figura 10 - Avanço dos sedimentos sobre a rodovia litorânea, próximo a comunidade de Pernambuquinho, município de Grossos, RN.

Fonte: Carvalho (2011).

Os campos de dunas apresentam sequências de "cadeias barcanóides" (SíGOLO, 2000, p. 258). As dunas assumem forma de meia lua com suas extremidades postas a sotavento. São observadas três unidades de concentração de dunas. A primeira, inicia-se a cerca de $700 \mathrm{~m}$ do nível do mar atual e se estende até aproximadamente $2.000 \mathrm{~m}$, possuindo cerca de 307 hectares (Figura 11) e representando uma geração de dunas de origem mais recente.

O segundo e o terceiro campo de dunas estão mais afastados da linha de costa atual, respectivamente a 2.500 e a 3.500 metros. O segundo ainda conserva a estrutura barcanóide, porém o terceiro já apresenta um abatimento da morfologia dunar. Poucas áreas possuem alguma estrutura vegetal consistente que seja capaz de reter a evolução das dunas migratórias.

As atividades de campo permitiram identificar que o material sedimentar presente nos campos de dunas possui calibre de areias finas. Esse fato pode explicar, junto à ação do vento e o regime pluviométrico escasso, a rápida migração dessas morfologias no sentido NE-SO. Vários problemas relacionados a dinâmica de sedimentos foram constatados como, por exemplo, o soterramento de casas, propriedades, tanques de salinas e estradas. Uma comunidade inteira, conhecida como "Durinho", foi obrigada a migrar em virtude do avanço das dunas sobre as casas, dando, assim, origem a atual comunidade de Valença. 


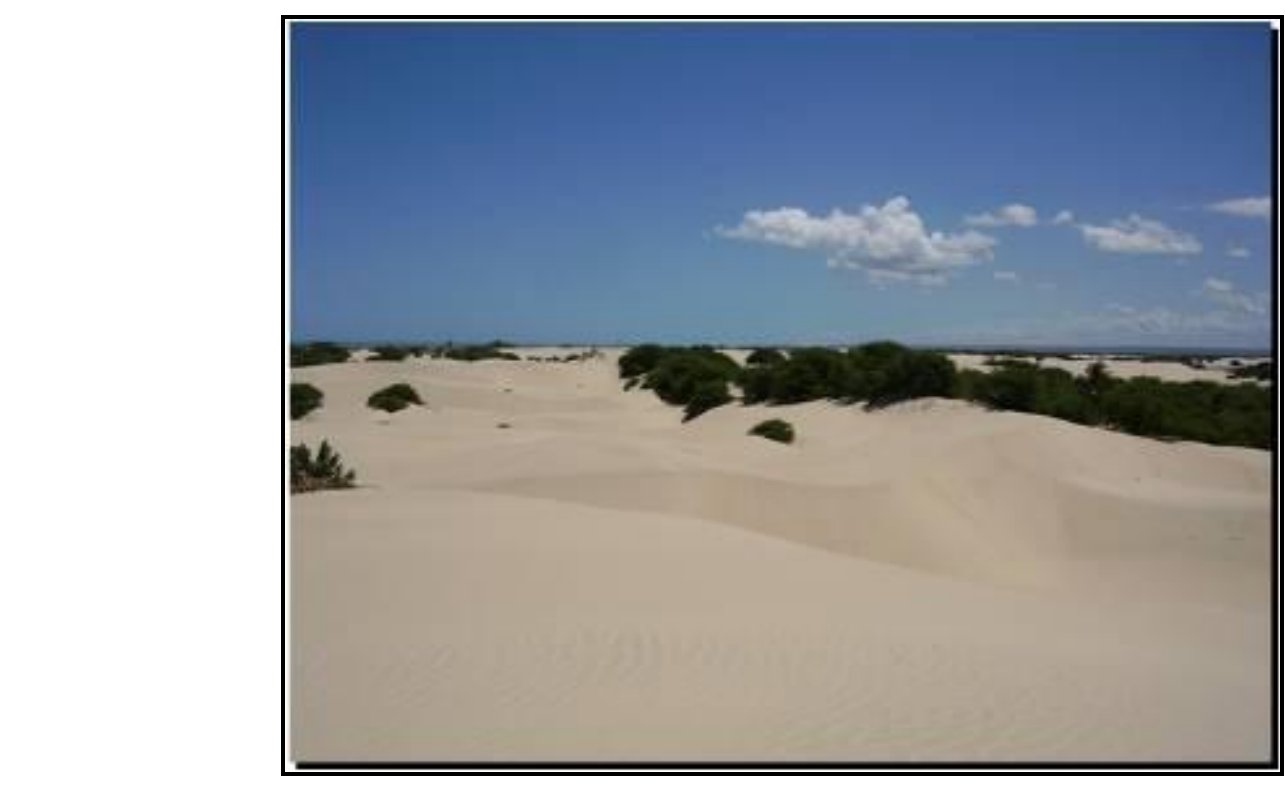

Figura 11 - Cadeia de dunas barcanóides próximo a comunidade de Areias Alvas, município de Grossos, RN. Fonte: Carvalho (2011).

O regime dinâmico do estuário está condicionado a fenômenos naturais como a oscilação das marés e a intensidade do regime pluviométrico na bacia de drenagem. Evidentemente, ações humanas, tais como os grandes barramentos e o bombeamento de água, tendem a alterar significativamente o sentido natural da dinâmica ambiental. Em entrevistas informais com pescadores e funcionários das salinas, observou-se uma preocupação com o nível de assoreamento do estuário, o qual chegou a provocar encalhes das barcaças (nome dado aos barcos especializados no transporte do sal até o Porto llha do município de Areia Branca).

O fluxo das barcaças, que há alguns anos era contínuo durante o dia, ocorre agora apenas em períodos de maré alta em virtude do estreitamento e assoreamento do canal principal. Além das atividades socioeconômicas, o fluxo de energia e matéria no sistema estuarino é responsável pela manutenção do ecossistema manguezal. No município de Grossos está uma das maiores áreas remanescentes desse ecossistema, próximo a comunidade de Barra.

No tabuleiro costeiro a dinâmica ambiental acontece de forma menos intensa. O significado dessa condição se resume em uma maior estabilidade da paisagem. O relevo aplainado, com suave rampeamento em direção ao litoral, diminui a intensidade dos processos de transporte superficial. Os fluxos de energia e matéria acontecem, porém com menos competência de transformação significativa da paisagem em um curto período de tempo, se comparados a planície litorânea e flúvio-marinha. A principal ação processual está relacionada ao regime pluvial, que determina o aumento da competência das águas superficiais no transporte de sedimentos e nutrientes. A erosão laminar é significativa nos 
primeiros eventos pluviométricos da estação chuvosa, quando a caatinga ainda está com baixa densidade de folhagens, todavia, a infiltração é favorecida pela alta permeabilidade do terreno e pelas condições planas do relevo, condicionando o aparecimento de lagoas intermitentes sazonais. Essa mesma infiltração também repercute na lixiviação dos latossolos presentes no tabuleiro costeiro.

\section{Potencialidades, limitações e problemas ambientais emergentes}

Foram qualificados os usos e os mecanismos de ocupação que tivessem relevância na dinâmica da paisagem e que representassem alterações visuais marcantes na superfície da terra. Assim sendo, partindo dessa lógica e, reconhecendo que esse é um trabalho de aproximação, foram arroladas 12 tipologias de espaços territoriais capazes de expressar o padrão de uso e cobertura da terra no município de Grossos (Tabela 2).

Tabela 2 - Tipologias de uso e cobertura da terra no município de Grossos - RN.

\begin{tabular}{llll}
\hline ATIVIDADE / ÁREA & (ha) & \% \\
\hline $\begin{array}{l}\text { Faixa de Praia e dunas frontais } \\
\text { Pecuária Extensiva / Extrativismo / }\end{array}$ & 158 & 1 \\
$\begin{array}{l}\text { Agricultura de Subsistência } \\
\text { Campos de Dunas / Recreação }\end{array}$ & 425 & 13 \\
Manguezal / Extrativismo & 132 & \\
Caatinga Arbustiva & 4040 & 1 \\
Agropecuária / Desmatamento & 3655 & 29 \\
Área Degradada / Salina & 78 & 27 \\
Agricultura /Salinas & 673 & 1 \\
Tanques / Salina Artesanal & 477 & 5 \\
Tanques / Salina Mecanizada & 1974 & 3 \\
Rio Apodi-Mossoró & 304 & 14 \\
Lagoas & 98 & 2 \\
\hline \multicolumn{2}{c}{ TOTAL } & Fonte: Carvalho (2011).
\end{tabular}

Percebe-se que as unidades de maior abrangência territorial são a Caatinga Arbustiva e a Agropecuária. Elas estão alocadas principalmente no tabuleiro costeiro, justificando-se aí suas destacadas extensões territoriais.

Representando $14 \%$ da área total do município, as Salinas Mecanizadas participam ativamente da economia local. Entre o ano de 1998 e 2010 a média anual da produção de sal no município de Grossos ficou em, aproximadamente, 299 toneladas/ano. O ano de 2000 foi o que teve a produção mais baixa, em torno de 179 toneladas, enquanto que o ano com maior produção foi 2002, com 356 toneladas (SIESAL, 2011). 
Com $13 \%$ de área ocupada, a pecuária extensiva abordada neste estudo está atrelada ao terraço marinho, representando meio de vida e subsistência de inúmeras famílias alocadas na planície litorânea e ocorrendo de forma pouco adensada. Atividades de extrativismo e agricultura de subsistência também são desenvolvidas em setores mais úmidos do terraço marinho. As outras atividades e/ou unidades delimitadas variam de 1 a $5 \%$ da área total do município (Figura 12).

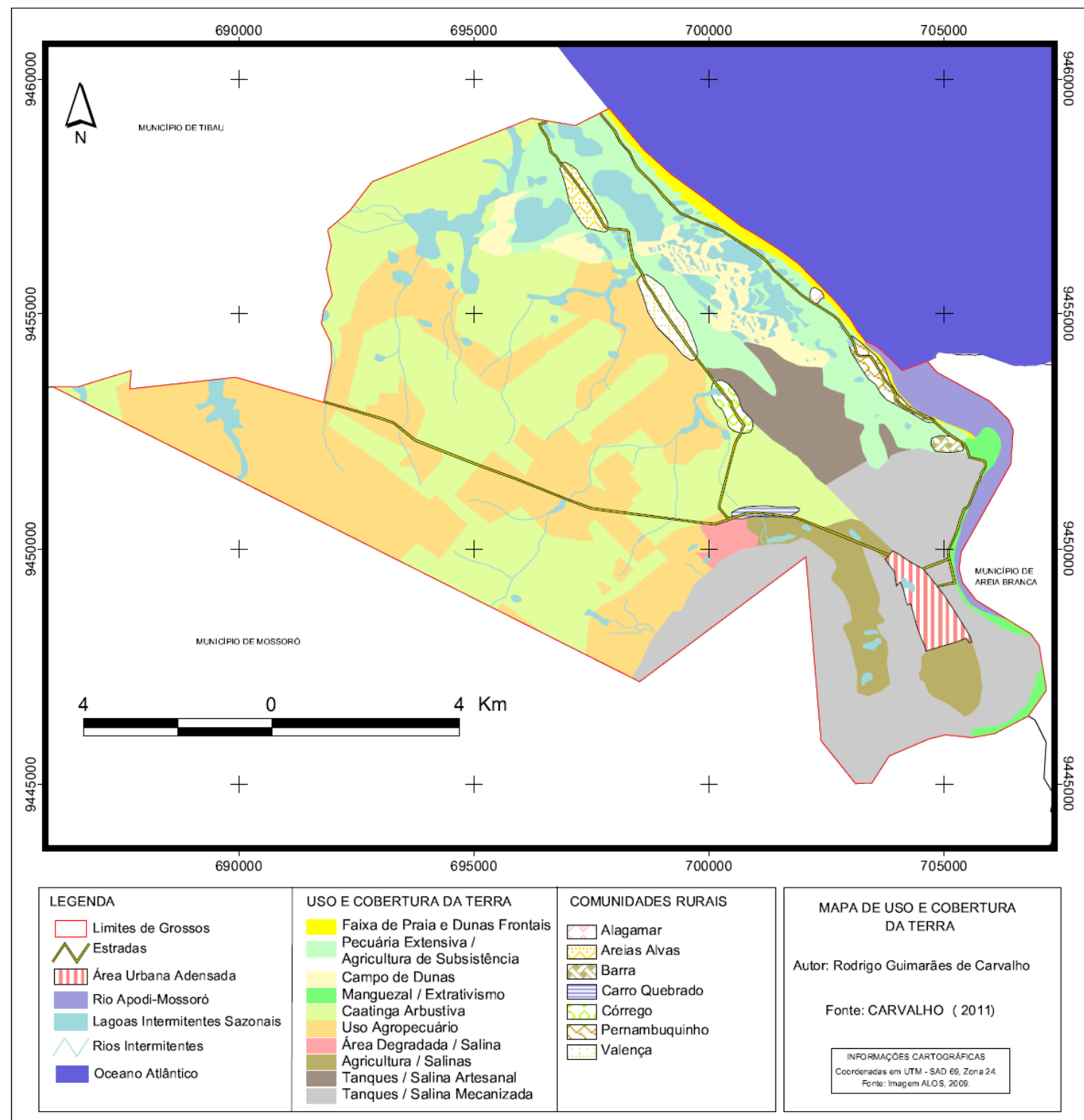

Figura 12 - Uso e cobertura da terra no município de Grossos, RN. Fonte: Carvalho (2011).

O Quadro 2 contém a síntese da análise dos sistemas ambientais locais, estando destacadas informações sobre as potencialidades e limitações, o uso e a ocupação atual, e os principais problemas observados nos sistemas ambientais do município de Grossos. O planejamento 
ambiental requer que sejam analisadas as potencialidades e limitações de cada um dos sistemas ambientais para que se desenhe um plano de ações de curto, médio e longo prazo, onde o principal viés deve ser o da sustentabilidade ambiental, econômica e social. A avaliação dos usos predominantes e dos problemas ambientais correlatos possibilita a adoção de medidas emergenciais para correção de situações indesejáveis e a hierarquização dos problemas admitindo-se critérios de prioridades.

A Figura 13 retrata alguns aspectos ambientais de Grossos, com destaque para alguns problemas que foram observados nos trabalhos de campo como, por exemplo, o acúmulo de lixo e a alteração da paisagem.

\begin{tabular}{|c|c|c|c|c|c|}
\hline $\begin{array}{l}\text { SISTEMAS } \\
\text { SUBSISTEN } \\
\text { AMBIENTA }\end{array}$ & & $\begin{array}{l}\text { POTENCIALIDADES } \\
\text { AO USO } \\
\text { OCUPAÇÃO }\end{array}$ & $\begin{array}{lr}\text { LIMITAÇÕES } & \text { AO } \\
\text { USO } & \text { E } \\
\text { OCUPAÇÃO } & \end{array}$ & $\begin{array}{l}\text { USO E OCUPAÇÃO } \\
\text { PREDOMINANTE }\end{array}$ & $\begin{array}{l}\text { PROBLEMAS } \\
\text { AMBIENTAIS }\end{array}$ \\
\hline $\begin{array}{l}\text { FAIXA } \\
\text { PRAIA } \\
\text { DUNAS } \\
\text { FRONTAIS }\end{array}$ & $\begin{array}{r}\text { DE } \\
\text { E }\end{array}$ & $\begin{array}{l}\text { Exploração turística } \\
\text { de baixo impacto } \\
\text { ambiental; educação } \\
\text { ambiental; pesca } \\
\text { artesanal; lazer; } \\
\text { esportes náuticos. }\end{array}$ & $\begin{array}{l}\text { Baixo suporte } \\
\text { para edificações; } \\
\text { estradas; solos } \\
\text { incipientes e de } \\
\text { baixa fertilidade; } \\
\text { restrições legais } \\
\text { ao uso da faixa } \\
\text { de praia e } \\
\text { terrenos } \\
\text { marinha. }\end{array}$ & 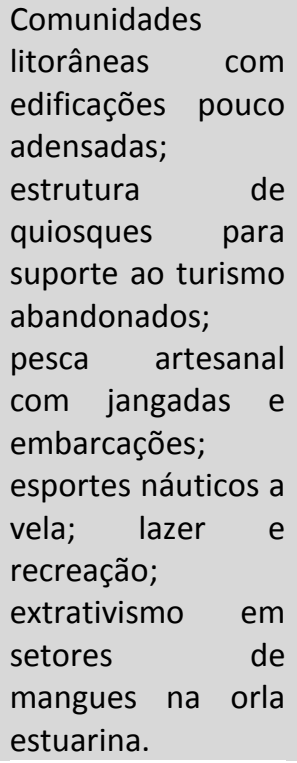 & $\begin{array}{l}\text { Construção de muros } \\
\text { de concreto para a } \\
\text { contenção do avanço } \\
\text { da areia da faixa de } \\
\text { praia; plantação de } \\
\text { algarobas } \\
\text { indiscrimidamente } \\
\text { para retenção de } \\
\text { sedimentos, de } \\
\text { disposição dé } \\
\text { resíduos sólidos de } \\
\text { forma pontual na } \\
\text { faixa de praia; } \\
\text { construção de } \\
\text { edificações sobre } \\
\text { dunas frontais. }\end{array}$ \\
\hline $\begin{array}{l}\text { TERRAÇO } \\
\text { MARINHO }\end{array}$ & & $\begin{array}{l}\text { Pecuária extensiva; } \\
\text { lazer; turismo } \\
\text { ecológico; pesquisa } \\
\text { arqueológica; } \\
\text { captação de água. }\end{array}$ & $\begin{array}{l}\text { Áreas de } \\
\text { inundação } \\
\text { sazonal; } \\
\text { presença de } \\
\text { sítios } \\
\text { arqueológicos; } \\
\text { restrições legais. }\end{array}$ & $\begin{array}{lr}\text { Pecuária extensiva } & \text { sem controle da } \\
\text { movimentação dos } & \text { de } \\
\text { animais; } & \text { uso } \\
\text { agrícola r de } & \text { pequenas áreas; } \\
\text { edificações } & \\
\text { residenciais. }\end{array}$ & $\begin{array}{l}\text { Plantação de } \\
\text { algarobas } \\
\text { indiscriminadamente; } \\
\text { destruição dos sítios } \\
\text { arqueológicos; } \\
\text { presença de } \\
\text { pequenos lixões. }\end{array}$ \\
\hline $\begin{array}{l}\text { CAMPOS } \\
\text { DUNAS } \\
\text { MÓVEIS }\end{array}$ & DE & $\begin{array}{l}\text { Turismo de baixo } \\
\text { impacto ambiental, } \\
\text { recreação e pesquisa } \\
\text { científica. }\end{array}$ & $\begin{array}{l}\text { Baixo suporte } \\
\text { para edificações; } \\
\text { estradas; } \\
\text { restrições legais; } \\
\text { ausência de } \\
\text { solos produtivos; } \\
\text { vegetação } \\
\text { esparsa; } \\
\text { restrição para } \\
\text { mineração. }\end{array}$ & $\begin{array}{l}\text { Lazer e recreação } \\
\text { principalmente nos } \\
\text { fins de semana e } \\
\text { utilizando as lagoas } \\
\text { interdunares; } \\
\text { presença } \\
\text { rebanhos de } \\
\text { transitando nas } \\
\text { dunas. }\end{array}$ & $\begin{array}{l}\text { Plantação de } \\
\text { algarobas } \\
\text { indiscriminadamente; } \\
\text { presença de fezes de } \\
\text { animais sobre as } \\
\text { dunas; } \\
\text { desmatamentos. }\end{array}$ \\
\hline
\end{tabular}




\begin{tabular}{|c|c|c|c|c|}
\hline $\begin{array}{l}\text { PLANÍCIE } \\
\text { FLÚVIO- } \\
\text { MARINHA }\end{array}$ & 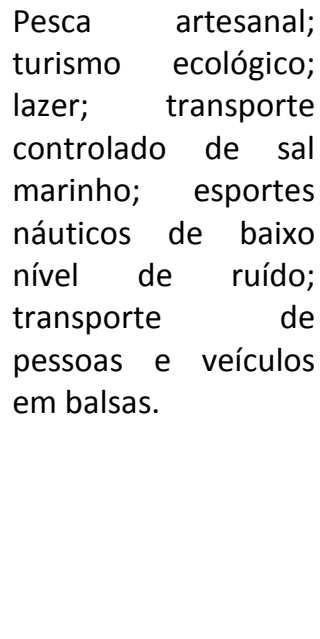 & $\begin{array}{l}\text { Ambiente com } \\
\text { rica diversidade } \\
\text { biológica; } \\
\text { cadeias tróficas } \\
\text { vulneráveis a } \\
\text { interferências } \\
\text { físicas, químicas } \\
\text { e biológicas; } \\
\text { restrição legal; } \\
\text { ambiente a } \\
\text { sensível poluição urbana } \\
\text { e industrial. }\end{array}$ & $\begin{array}{lr}\text { Deposição } & \text { de } \\
\text { detritos e esgotos } \\
\text { urbanos; deposição } \\
\text { de produtos } \\
\text { químicos r e } \\
\text { biológicos; pesca } \\
\text { artesanal; } \\
\text { extrativismo; } \\
\text { trânsito de balsas e } \\
\text { barcaças de sal } \\
\text { permanentemente; } \\
\text { captação } \\
\text { permanente de } \\
\text { água para as } \\
\text { salinas. }\end{array}$ & $\begin{array}{l}\text { Poluição física, } \\
\text { química e biológica } \\
\text { do estuário e do } \\
\text { manguezal; ocupação } \\
\text { com tanques } \\
\text { evaporadores e } \\
\text { cristalizadores } \\
\text { disposição de águas- } \\
\text { mãe pelas salinas; } \\
\text { desmatamento e } \\
\text { coleta indiscriminada } \\
\text { de espécies da fauna } \\
\text { do manguezal. }\end{array}$ \\
\hline $\begin{array}{l}\text { PLANÍCIE } \\
\text { FLÚVIO- } \\
\text { LACUSTRE }\end{array}$ & $\begin{array}{l}\text { Uso controlado do } \\
\text { solo para atividades } \\
\text { de subsistência; } \\
\text { águas subterrâneas; } \\
\text { lazer e recreação; } \\
\text { ecoturismo. }\end{array}$ & $\begin{array}{l}\text { Restrição legal } \\
\text { ao uso das } \\
\text { margens de rios } \\
\text { e lagoas; áreas } \\
\text { sensíveis a } \\
\text { poluição } \\
\text { ambiental; baixo } \\
\text { suporte para } \\
\text { edificações; } \\
\text { inundações } \\
\text { sazonais. }\end{array}$ & $\begin{array}{l}\text { Agropecuária; } \\
\text { atividades agrícolas } \\
\text { de subsistência. }\end{array}$ & $\begin{array}{lr}\text { Desmatamento } & \text { da } \\
\text { vegetação } & \text { ciliar; } \\
\text { disposição } & \text { de } \\
\text { resíduos sólidos } & \text { e } \\
\text { líquidos; } & \text { uso } \\
\text { indiscriminado } & \text { da } \\
\text { água. } & \end{array}$ \\
\hline $\begin{array}{l}\text { TABULEIRO } \\
\text { COSTEIRO }\end{array}$ & 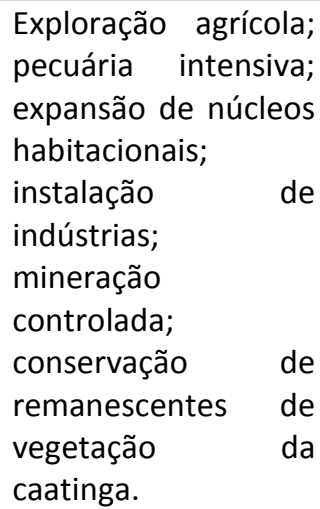 & $\begin{array}{l}\text { Restrição de } \\
\text { recursos } \\
\text { hídricos. }\end{array}$ & Uso agropecuário. & $\begin{array}{lr}\begin{array}{l}\text { Desmatamentos } \\
\text { controle sem }\end{array} \\
\text { ambiente } & \text { em } \\
\text { caatinga; } & \text { de } \\
\text { desmatamento de } \\
\text { vegetações ciliares; } \\
\text { presença } \\
\text { pequenos lixões. de }\end{array}$ \\
\hline $\begin{array}{c}\text { CHAPADA DO } \\
\text { APODI }\end{array}$ & $\begin{array}{l}\text { Uso agropecuário } \\
\text { controlado; } \\
\text { expansão de núcleos } \\
\text { habitacionais. }\end{array}$ & $\begin{array}{l}\text { Ambientes com } \\
\text { declividade } \\
\text { acentuada; } \\
\text { riscos de erosão } \\
\text { linear. }\end{array}$ & $\begin{array}{c}\text { Ocupação por } \\
\text { atividades } \\
\text { agropecuárias; } \\
\text { galpões de } \\
\text { armazenamento de } \\
\text { sal; indústria } \\
\text { salineira. }\end{array}$ & $\begin{array}{l}\text { Desmatamentos por } \\
\text { toda a área; } \\
\text { aterramentos para } \\
\text { implantação de vias. }\end{array}$ \\
\hline
\end{tabular}

Quadro 2 - Síntese da análise ambiental integrada no município de Grossos.

Fonte: Adaptado de Carvalho (2011). 


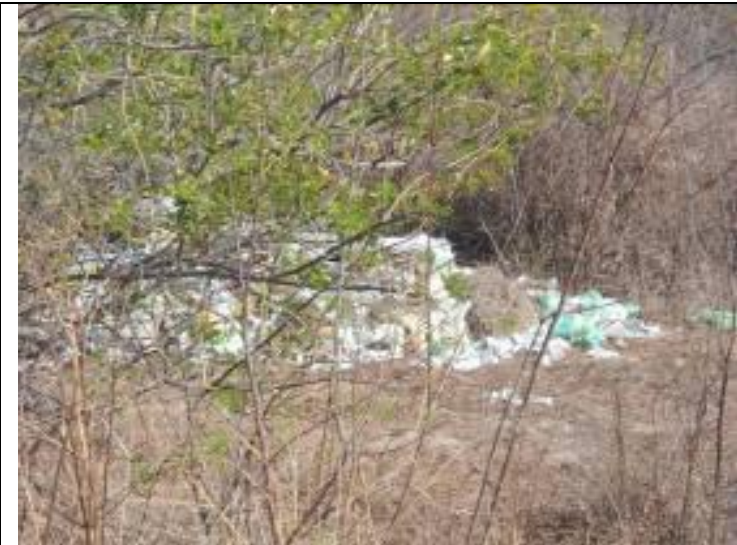

A

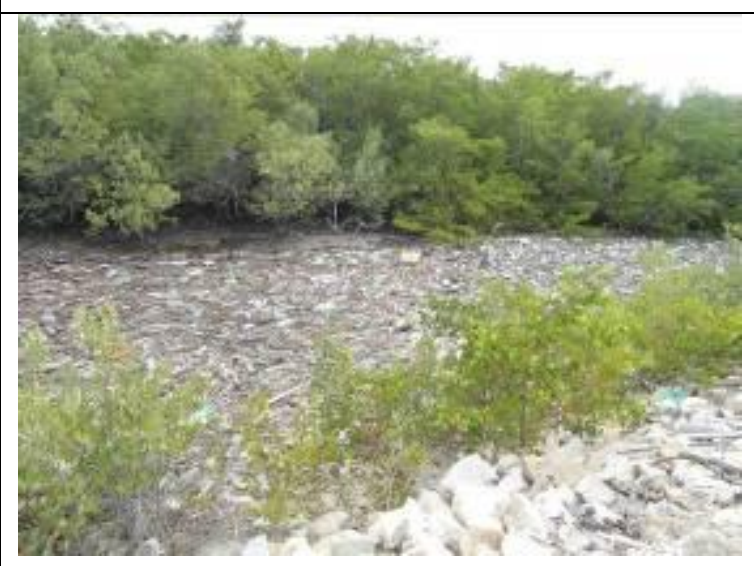

C

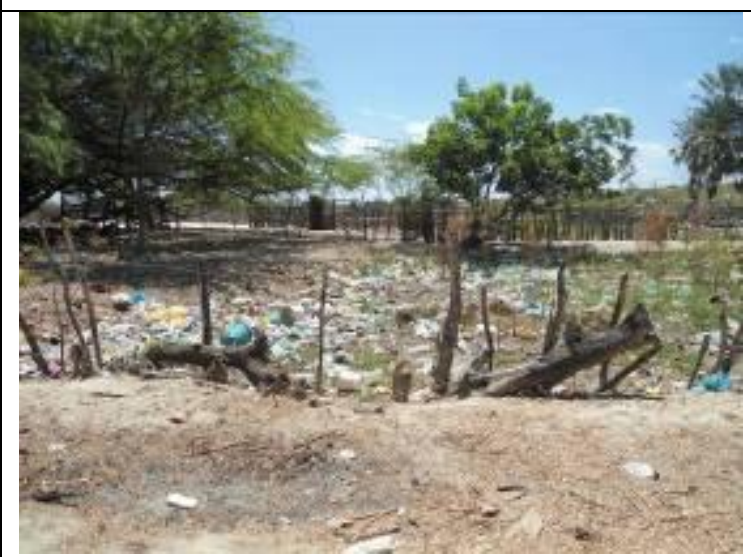

E

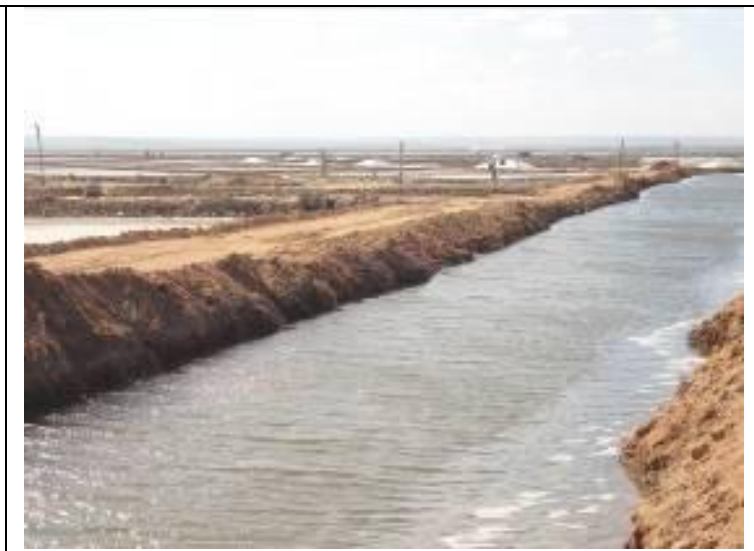

B

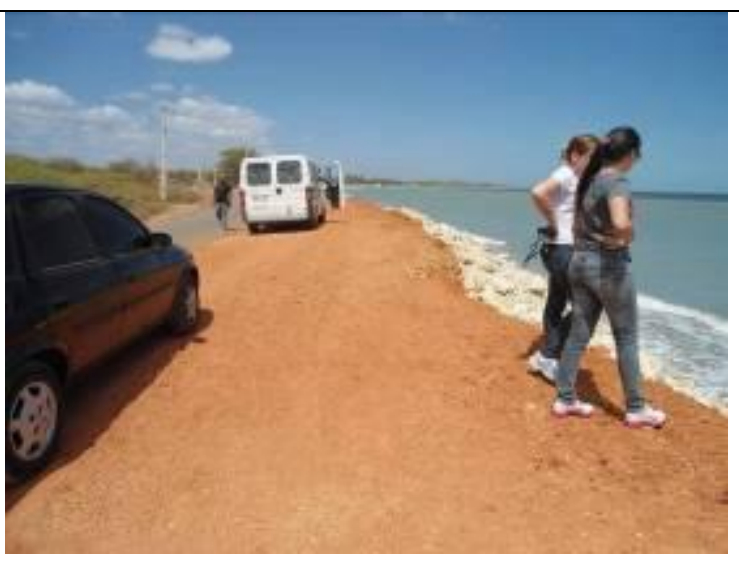

D

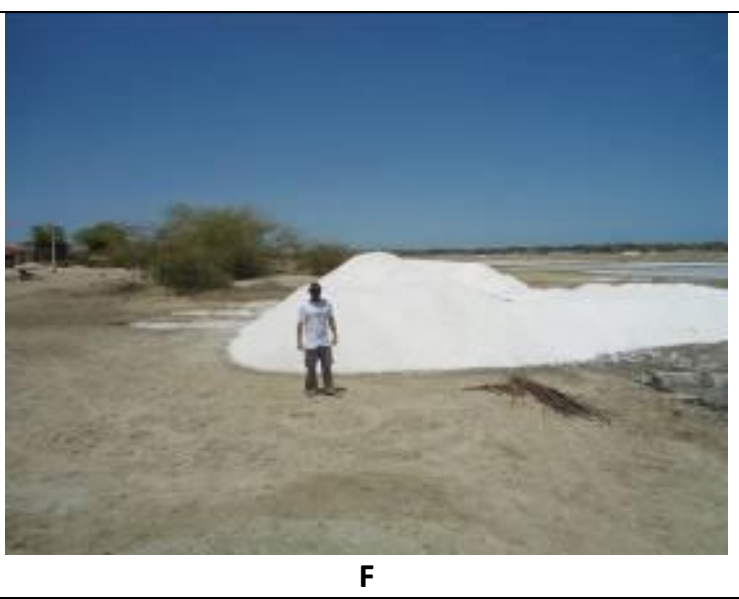

Figura 13 - Aspectos ambientais do município de Grossos. A) concentração de lixo sobre o tabuleiro costeiro. B) Canais e tanques das salinas mecanizadas. C) Acumulação de lixo no manguezal próximo a comunidade de Barra. D) Construção de aterro e enrocamento para conter o avanço do mar sobre a rodovia litorânea. E) Concentração de lixo no terraço marinho. F) Monte de sal nas salinas artesanais.

Fonte: Acervo de Rodrigo Guimarães de Carvalho, dezembro de 2011. 


\section{CONSIDERAÇÕES FINAIS}

O diagnóstico ambiental integrado do município de Grossos revela a existência de um mosaico de sistemas ambientais com aptidões de uso e fragilidades naturais diversas. Verifica-se que as atividades socioeconômicas vêm se desenvolvendo de acordo com as oportunidades de utilização dos recursos naturais disponíveis em cada um dos sistemas ambientais, havendo, no entanto, sistemas subutilizados, e outros superutilizados, tendo como repercussão direta uma complexa cadeia de impactos ambientais.

A maior parte do município apresenta potencial para o uso intensivo, que pode ser desenvolvido no tabuleiro costeiro. A área sob domínio das salinas mecanizadas e artesanais foi completamente alterada, de modo que, por estar intimamente ligada a dinâmica do estuário e do manguezal, devem ser requeridas adaptações com o objetivo de minimizar os problemas ambientais, especialmente os relacionados à poluição do rio Apodi-Mossoró e ao desmatamento da vegetação de mangue.

A planície litorânea apresenta potencial para o desenvolvimento de atividade turística como alternativa para a geração de renda local. As belezas naturais das praias, dos campos de dunas e os sítios arqueológicos são características que devem ser valorizadas no incremento desse ramo de atividades.

A presente pesquisa representa um subsídio importante para o desenvolvimento de programas de ordenamento territorial e do zoneamento ecológico-econômico no município de Grossos. O planejamento é um instrumento fundamental para o alcance da sustentabilidade, e, no caso de Grossos, torna-se ainda mais importante devido à existência de inúmeras atividades socioeconômicas impactantes e de sistemas ambientais de elevada fragilidade natural.

\section{REFERÊNCIAS BIBLIOGRÁFICAS}

BERTRAND, G. Paisagem e Geografia Física global: esboço metodológico. In: Caderno de Ciências da Terra, v. 13, p. 1-21. São Paulo, 1969.

BERTRAND, G.; BERTRAND C. Uma geografia transversal e de travessias: o meio ambiente através dos territórios e das temporalidades. In: PASSOS, M. M. dos. (org.) Maringá: Ed. Massoni, 2007. 
CARVALHO, R. G. de, Análise de sistemas ambientais aplicada ao planejamento: estudo em macro e mesoescala na região da bacia hidrográfica do rio Apodi-Mossoró, RN/Brasil. 2011. Tese de Doutorado em Geografia/UFC. Fortaleza, 2011.

CHRISTOFOLETTI, A. Modelagem em Sistemas Ambientais. São Paulo: Edgard Blücher, 1999.

CPRM - Serviço Geológico do Brasil. Projeto cadastro de fontes de abastecimento de águas subterrâneas: diagnóstico do município de Grossos, Rio Grande do Norte. Recife, 2005.

HESP, P. A gênese de cristas de praia e dunas frontais. Mercator - Revista de Geografia da UFC, ano 01, número 02, 2002.

IDEMA - Instituto de Desenvolvimento Sustentável e Meio Ambiente do RN. [entre 2000 e 2010]. Disponível em: http://www.idema.rn.gov.br/contentproducao/aplicacao/idema/socio_economicos/enviado s/perfil_g.asp. Acesso em 13/01/2011.

MACEDO, R. K. de. A importância da avaliação ambiental. In: TAUK, S. M. (org.) Análise Ambiental: uma visão multidisciplinar. $2^{a}$ Edição. São Paulo: Editora da Universidade Estadual Paulista, 1995.

MEIRELES, A. J. A.; SILVA, E. V. da.; THIERS, P. R. L. Os campos de dunas móveis: fundamentos dinâmicos para um modelo integrado de planejamento e gestão da zona costeira. Revista GEOUSP - Espaço e Tempo, São Paulo, n² 20, p. 101 - 119, 2006.

MMA - Ministério do Meio Ambiente. Monitoramento do desmatamento dos biomas brasileiros por satélite / Monitoramento do bioma caatinga. (Relatório Técnico). Centro de Sensoriamento Remoto, Brasília, 2010. Acesso em 25 de março de 2010. Disponível em: http://www.mma.gov.br/sitio/index.php?ido=conteudo.monta\&idEstrutura=146

RABELO, L. P.; BRITO, P. O. A importância das dunas frontais na avaliação da evolução da linha de costa. V Encontro de professores de geociências de Algarve, Vila Real de Santo António , 2004.

RODRIGUEZ, J. M. M. et al. Experiencias de planejamento ambiental em Brasil usando La concepicion de La geoecologia de los paisajes ("landscape planning"). In: Silva et al. 
(organizadores). Gestão dos recursos hídricos e planejamento ambiental. João Pessoa: Editora Universitária da UFPB, 2010.

SANTOS, R. F. Planejamento Ambiental: teoria e prática. São Paulo: Oficina de Textos, 2004.

SEMARH - Secretaria de Estado dos Recursos Hídricos. Plano Estadual de Recursos Hídricos. Natal, 1998.

SIESAL - Sindicato da Indústria da Extração do Sal no Estado do Rio Grande do Norte. Relatório Técnico, 2011.

SÍGOLO, J. B. Processos eólicos: a ação do vento. In: TEIXEIRA, W. et al. Decifrando a Terra. São Paulo: Oficina de Textos, 2000.

SILVA, E. V. da. Geoecologia da paisagem do litoral cearense: uma abordagem a nível de escola regional e tipológica. Tese de Professor Titular, Departamento de Geografia, UFC, Fortaleza, 1998.

SIQUEIRA, L. A., ARAGÃO, W. M., TUPINAMBÁ, L. A. A introdução do coqueiro no Brasil, importância histórica e agronômica. 24p, 2002. (Embrapa Tabuleiros Costeiros. Documentos, 47). Acesso em: 20/01/2011. Disponível em: http://www.cpatc.embrapa.br/download/Documentos47.pdf

VITAL, H. Rio Grande do Norte. In: MUEHE, D. (org.). Erosão e progradação do litoral brasileiro. Brasilia, MMA, 2006

Artigo recebido em 18/01/2012.

Artigo aceito em 03/02/2012. 